\title{
Spatiotemporal variation and socioeconomic factors of financial hardships of out-of-pocket health expenditure in Pakistan
}

Ashar Muhammad Malik, Iqbal Azam, ${ }^{1}$ Amir Khan, ${ }^{2}$ Faisal Rifaq ${ }^{3}$ and Kinza Chaudhary ${ }^{1}$

${ }^{1}$ Community Health Sciences Department, Aga Khan University, Karachi, Pakistan (Correspondence to: Ashar Muhammad Malik: ashar.malik@aku. edu). ${ }^{2}$ Institute of Business Administration, Karachi, Pakistan ${ }^{3}$ Sehat Sahulat Programme, Ministry of National Health Services, Regulations and Coordination, Islamabad, Pakistan.

\begin{abstract}
Background: Financial hardships of out-of-pocket health expenditure (OPHE) is a growing concern for health policy makers in many low and middle-income countries. Spatiotemporal variation between Pakistan's four provinces over $2001-2015$ is discussed, which would help comparing existing health services delivery and financial risk protection plans.

Aims: In this paper, we estimate financial hardship of OPHE in Pakistan.

Methods: We use the data sets of the household integrated economic surveys 2001-02, 2005-06, 2010-11 and 2015-16. We estimate OPHE share in household total and non-subsistence expenditure, catastrophic headcount at the threshold of OPHE $\geq 10 \%$ of total expenditure or OPHE $\geq 25 \%$ of non-subsistence expenditure. We estimate impoverishment of OPHE using national poverty lines. Finally, we explore socioeconomic factors of financial hardships of OPHE.

Results: Over the years, catastrophic headcount and impoverishment of OPHE had decreased at national level (-1.3\% points) and in the provinces of Sindh (-7.8\% points) and Khyber Pukhtoonkhawa (KPK), (-2.8\% points). The province of KPK and the year 2005-06 witnessed the highest incidence of financial catastrophe (26.89\% points) and impoverishment (4.8\% points) of OPHE. Households in rural areas, in the middle and rich quintiles and those headed by a male were more likely to encounter financial catastrophe and impoverishment due to OPHE.

Conclusion: Inter-provincial variation in financial hardships of OPHE provide aide to provincial level priority setting. The high impact of OPHE in the non-poor, in rural areas, and in KPK calls for enhanced targeting of financial risk protection plans.

Keywords: out-of-pocket health expenditure, interrupted time series analysis, spatial analysis, financial catastrophe, Pakistan

Citation: Malik AM; Kazmi S; Khan A; Rifaq F; Chaudhary K. Spatiotemporal variation and socioeconomic factors of financial hardships of out-of-pocket health expenditure in Pakistan. East Mediterr Health J. 2021;27(10):962-973. https://doi.org/10.26719/emhj.21.045

Received: 23/11/20; accepted: 01/03/21

Copyright (C) World Health Organization (WHO) 2021. Open Access. Some rights reserved. This work is available under the CC BY-NC-SA 3.0 IGO license (https://creativecommons.org/licenses/by-nc-sa/3.o/igo).
\end{abstract}

\section{Introduction}

\section{Historical background}

Health care financing is an area of low priority in health policy formulation and analysis in Pakistan. The country is not included in the Universal Health Coverage Study Series group: low- and middle-income countries (LMICs) that are implementing major reforms to achieve universal health care (1). In contrast with other countries in the region (Bangladesh 1996-97, India 1997, Nepal 1997, Sri Lanka 1995), Pakistan only produced its first national health accounts in 2008 (2). Public expenditure reviews and health care financing analyses are rarely carried out (3). During the 200os, Pakistan ignored many global and regional efforts to track progress on financial risk protection. For instance, in the World Health Organization (WHO) study on financial catastrophe in 59 countries, Bangladesh and Sri Lanka were included from south Asia (4). In the research collaboration on financial hardships of out-of-pocket health expenditure (OPHE) in 11 Asian countries, Bangladesh, India, Nepal, and Sri Lanka participated from the south Asian region $(5,6)$. In the second round of the WHO study, the number of countries in- creased from 59 to 89, still excluding Pakistan (7). In the section on financial hardships of OPHE, one of the background papers of the 2010 World Health Report included Bangladesh, India, Nepal and Sri Lanka from south Asia (8). The WHO and World Bank joint project on universal health coverage case studies from 13 LMICs included Bangladesh and India (9).

As a backdrop to the fact that financial risk protection and universal health coverage have been included in the United Nations Agenda 2030, since 2015, analyses of financial hardships of OPHE have been common for all United Nations Member States, including Pakistan (10-13). The purpose of such efforts is comparison across countries. Pakistan has significant ethnic/linguistic diversity across provinces (Table 1) and the health sector is a provincial matter, thus, evidence on financial risk protection should include subnational and time trend analysis.

\section{Health care financing trends}

Health care financing in Pakistan is predominately private out-of-pocket with some improvement over the years (Figure 1). For example, during 2001-2015, the share 


\section{Figure 1 Health care financing mix in Pakistan 2005-06 to 2015-16; source: National Health Accounts}
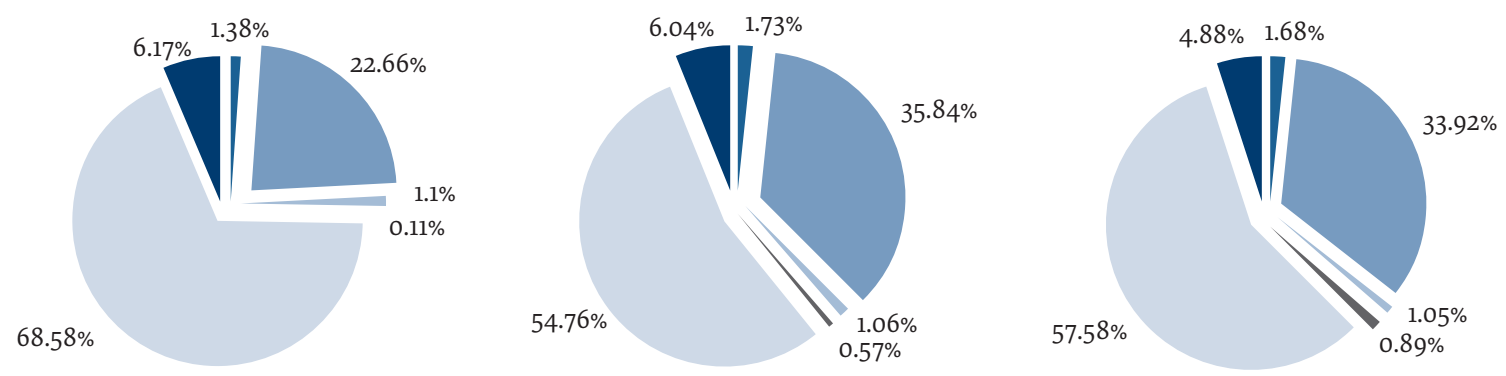

Puclic

Employers fund

Private health insurance

Households

NGOs

Donors

of public health expenditure increased from $23 \%$ to $34 \%$ of the total health expenditure. This was accompanied by a decrease in the share of OPHE in current health expenditure: $68 \%$ (2005) to $58 \%$ (2015) (2).

Currently, 2 large-scale financial risk protection schemes are operating in the country managed by the provincial government of Khyber Pakhtunkhwa (KPK) and the federal government $(14,15)$. These schemes target the population living below the poverty line and provide coverage for inpatient care with an enrolment of 2.6 million and 6.9 million families respectively. Independent sources, however, report a coverage of $0-3 \%$ for these programmes (Table 1).

\section{Aims}

The existing literature on the financial hardships from OPHE in Pakistan is limited to a few grey reports that used very old (2003-2004) cross-sectional datasets $(16,17)$.
Multi-country analysis provides a national-level estimate of financial hardship in Pakistan but ignores subnational analysis, time trends and socioeconomic determinants of financial hardship of OPHE (10-13).

In this study, we track progress on financial risk protection over the period 2001-2016. We explore whether the economic growth of the country, a decline in the incidence of poverty (Table 2 ) and an improvement in the texture of health care financing has contained the financial hardships of OPHE. We provide subnationallevel analysis due to the ethnic/cultural diversity of the provinces (Table 1) and the fact that since 2010, the health sector has been a provincial matter. We hypothesize that financial hardship from OPHE has decreased at national and provincial levels. Lastly, we explore the influence of socioeconomic factors on OPHE and its financial hardships on households.

\begin{tabular}{|c|c|c|c|c|}
\hline Feature & Sindh & Baluchistan & KPK & Punjab \\
\hline Area, $\mathrm{km}^{2}(\% \text { of total })^{\mathrm{a}}$ & $\begin{array}{l}140914 \\
(17.7 \%)\end{array}$ & $\begin{array}{l}347190 \\
(43.6 \%)\end{array}$ & $\begin{array}{l}74521 \\
(9.4 \%)\end{array}$ & $\begin{array}{l}205345 \\
(25.8 \%)\end{array}$ \\
\hline Population, thousands (\% of total) $)^{a}$ & $\begin{array}{c}47886 \\
(23)\end{array}$ & $\begin{array}{c}12344 \\
(6)\end{array}$ & $\begin{array}{l}30523 \\
(15)\end{array}$ & $\begin{array}{c}110012 \\
(53)\end{array}$ \\
\hline Rural share in total population (\%) $)^{a}$ & $48 \%$ & $72.5 \%$ & $81.2 \%$ & $63.3 \%$ \\
\hline Language spoken (\% of province) $)^{a}$ & $\begin{array}{l}\text { Sindhi (59.7) } \\
\text { Urdu (21.0) }\end{array}$ & $\begin{array}{l}\text { Balochi (54.8) } \\
\text { Pashto (29.6) }\end{array}$ & $\begin{array}{l}\text { Pashto (73.9) } \\
\text { Hindko (3.9) }\end{array}$ & $\begin{array}{l}\text { Punjabi (75.2) } \\
\text { Saraiki (17.4) }\end{array}$ \\
\hline Literacy rate $(\%)$ & 62.2 & 55.5 & $55 \cdot 3$ & 64.7 \\
\hline Life expectancy (years) $)^{b}$ & 67.2 & 67 & 68.8 & 66.3 \\
\hline Under 5 mortality rate (deaths per 1000 live births) ${ }^{b}$ & 77 & 78 & 64 & 85 \\
\hline Maternal mortality ratio (deaths per 100 ooo live births) ${ }^{b}$ & 314 & 785 & 275 & 227 \\
\hline Share in national income $(\%)^{c}$ & 30 & 3 & 13 & 55 \\
\hline Share in industries $(\%)$ & 28 & 3 & 11 & 58 \\
\hline Share in foreign remittance (\%) & 1.5 & 1.1 & 27.5 & 59.9 \\
\hline \multicolumn{5}{|l|}{ Sehut Sahult programme coverage (\%) } \\
\hline Women & 0.1 & 0.1 & 2.8 & 0.3 \\
\hline Men & 0 & 0.1 & 0.1 & 1.2 \\
\hline
\end{tabular}

a(Pakistan Bureau of Statistics 2017: https://www.pbs.gov.pk/content/provisional-summary-results-6th-population-and-housing-census-2017-o)

${ }^{b}$ Pakistan Demographic and Health Survey. Islamabad: Institute of Population Studies and DHS program ICF 2007; 2019

c(Pasha HA. Growth of the provincial economies. Lahore: Institute for Policy Reforms; 2015 (https://ipr.org.pk/wp-content/uploads/2016/04/GROWTH-OF-PROVINCIAL-ECONOMICS-.pdf). KPK = Khyber Pakhtunkhwa. 


\begin{tabular}{lcccc}
\hline Table 2 Socioeconomic and demographic transition in Pakistan 2000-2016 & & \\
& $\mathbf{2 0 0 1 - 0 2}$ & $\mathbf{2 0 0 5 - 0 6}$ & $\mathbf{2 0 1 0 - 1 1}$ & $\mathbf{2 0 1 5 - 1 6}$ \\
\hline Population (million) $^{\mathrm{a}}$ & 146 & 164 & 183 & 199 \\
Rural share in population (\%) $^{\mathrm{a}}$ & 52.9 & 50.4 & 47.9 & 45.6 \\
GDP per capita (US\$) $^{\mathrm{b}}$ & 495 & 837 & 1165 & 1368 \\
GDP annual growth rate (\%) & 3.6 & 6.5 & 2.8 & 4.7 \\
Share of agriculture in GDP (\%) & 24.1 & 21.6 & 21.7 & 19.9 \\
GINI index $^{\mathrm{b}}$ & 30.4 & 32.7 & 29.8 & 33.5 \\
\hline
\end{tabular}

${ }^{a}$ Source $=$ Pakistan Bureau of Statistics Population Census of Pakistan 2017. Provincial summary results (https://www.pbs.gov.pk/content/provisional-summary-results-6th-population-andhousing-census-2017-0).

${ }^{b}$ Source = Finance Division. Economic Survey of Pakistan 2015-16, Government of Pakistan, 2016 (http://www.finance.gov.pk/survey_1516.html).

'Source = World Bank. Open Data. 2016 (https://data.worldbank.org/country/pakistan).

\section{Methods}

\section{Data sources and description}

We use data sets of 4 rounds (i.e. $2001-02, n=16$ 182;2005$06, n=15444 ; 2010-11, n=16341$; and 2015-16, $n=24$ 238) of the Household Integrated Economic Survey conducted by the Pakistan Bureau of Statistics of the Government of Pakistan (links available at: (https://www.pbs.gov.pk/ pslm-publications). It captures a detailed profile of income and expenditure of the population at the household level. The survey uses 2-stage cluster sampling and the sample size is representative at national and provincial levels in all rounds.

Total expenditure of the household in the Household Integrated Economic Survey covers approximately 155 questions using recalls of 2 weeks, 1 month and 1 year.

The yearly total expenditure of the household is the sum of fortnightly expenditures (multiplied by 26), monthly expenditures (multiplied by 12) and yearly expenditures. Non-subsistence expenditure of the household is the total expenditure of the household less subsistence expenditure. We define subsistence expenditure as the expenditure on food items, utilities and fuel, laundry and personal care. To estimate yearly expenditure, we multiply expenditure on 2-week and 4-week recall by a factor of 26 and 12 respectively.

Yearly recall for OPHE was reported as an aggregate at household level. It includes expenditure on medical products and services and excludes health insurance premiums. The recall period for OPHE remained the same over 2001-16, but the questions on OPHE differed. In 2001-02, there were 4 items on OPHE: medicines and appliances, doctors' fees, hospitalization and dental and ophthalmic care (available via: (https://www.pbs. gov.pk/pslm-publications). The Household Integrated Economic Survey of 2005-06 and 2010-11 had 2 items on OPHE: medicines and other over-the-counter products and doctors' fees, and expenditure on hospitalization and all other types of care (Pakistan Bureau of Statistics, 2005-2010). In the Household Integrated Economic Survey 2015-16, there were 34 items on OPHE divided into 3 sections: section 1 had 12 items on over-the-counter purchase, section 2 had 10 items on ambulatory care. Section 3 had 12 items on hospitalization.
For 2001-02, 2005-06, 2010-11 and 2015-16, 89.66\%, $99.22 \%, 99.28 \%$ and $99.93 \%$ of the sample respectively reported non-zero OPHE. After cleaning the data, the combined sample was 68872 households.

\section{Analytical approach}

We estimate OPHE in Pakistan rupees (PKR) 2015-16 constant prices. Using the methods of O'Donnell et al., we analysed the absolute and relative financial hardship from OPHE, i.e. impoverishment and financial catastrophe (18).

A financial catastrophe occurs to a household if their OPHE exceeds a certain threshold (proportion) of their income or expenditure. If $O P H E_{i}$ is the out-of-pocket health payment of the ith household and $X_{i}$ is their total (non-subsistence) expenditure, then the ith household encounters a financial catastrophe $\left(E_{i}\right)$ if the share of $\mathrm{OPHE}_{i}$ in $\mathrm{X}_{i}$ exceeds the threshold value $Z$, i.e. <equation>

$$
E_{i}=\frac{O P H E_{i}}{X_{i}} \geq z
$$

where $z$ represents the point where spending on health could create financial hardships for the household.

Due to substantial informal sector and non-market transactions in LMICs, household expenditure is a better proxy of household economic status than household income (18). We used 2 types of household expenditure to estimate financial catastrophe: household total expenditure and non-subsistence expenditure. The argument in favour of using non-subsistence expenditure is that subsistence expenditure is usually non-discretionary and household total expenditure net of subsistence expenditure provides a better understating of the catastrophic impact of OPHE (18). We used 2 threshold values of $z$ to estimate financial catastrophe, OPHE exceeding $10 \%$ of the total expenditure $\left(\mathrm{CH}_{10}\right)$ and OPHE exceeding $25 \%$ of non-subsistence expenditure $\left(\mathrm{CH}_{25}\right)$ (18). The catastrophic headcount $(\mathrm{CH})$ is the proportion of households that had encountered financial catastrophe, i.e.

$$
C H=\frac{1}{N} \sum_{i=1}^{N} E_{i}
$$


To analyse the distributional aspect of OPHE and catastrophic incidence, we estimated concentration indices (CI) of $\mathrm{CH}_{10}$ and $\mathrm{CH}_{25}$. We used convenient regression methods to compute the concentration indices (18).

$$
2 \delta_{r}^{2}\left(\frac{o_{i}}{\mu}\right)=\alpha+\beta r_{i}+\varepsilon_{i}
$$

In this equation, $o_{i}$ is OPHE of the ith household, $\mu$ is the mean of OPHE, $\delta$ is the variance of frictional rank and $r_{i}$ is the fractional rank of the household by their total expenditure or non-subsistence expenditure (18).

We estimated the effect of OPHE on poverty headcount $\left(\mathrm{H}_{\mathrm{imp}}\right)$ as the difference between poverty headcount gross of total expenditure and poverty headcount of total expenditure net of OPHE.

$H_{\text {imp }}=$ Poverty headcount $_{\text {gross }}-$ Poverty headcount $_{\text {net }}$

Where poverty headcount is:

$$
\text { Poverty headcount } t_{\text {gross }}=\frac{\sum_{i=1}^{N} s_{i} p_{i}^{\text {gross }}}{\sum_{i=1}^{N} s_{i}}
$$

$p_{i}^{g r o s s}$ is 1 if the household expenditure is > poverty line; $s_{i}$ is the size of the household and $N$ is the number of households. Poverty headcount ${ }_{n s t}$ can be estimated by the same analogy (18).

We used the official national poverty line of the government of Pakistan, which uses the basic development needs approach (19). The poverty lines were available for the years 2005-06, 2010-11 and 2015-16.
For 2001-02, we deflated the poverty line of 2005-06 to 2001-02 using consumer price indices (20). In addition to headcount, we estimated catastrophic overshoot and normalized poverty gap (Supplementary Tables 1,2), i.e. the amount a household falls short of the catastrophic threshold or poverty line respectively (18).

Finally, we analysed the influences of the socioeconomic and demographic features of the household on financial hardship of OPHE. We used the Probit regression on each binary outcome $\left(\mathrm{CH}_{10}, \mathrm{CH}_{25}\right.$ and $\mathrm{H}_{\text {imp }}$, denoted by $\mathrm{Y}$ in the equation below) and including the vector of 9 covariates: gender, age, schooling, marital status of the head of the household, household size, rural households, quintiles, provinces and year of survey.

$P\left(Y_{i}=1 \mid X_{i j}\right)=\Phi\left(\beta 0+\beta_{1}\right.$ Gender $+\beta_{2}$ Age $+\beta_{3}$ Schooling + $\beta_{4}$ MaritalStatus $+\beta_{5}$ HHsize $+\beta_{6}$ Rural $+\beta_{7}$ Quintiles $+\beta_{8}$ Province $+\beta_{9}$ Year $+\varepsilon$ )

Where $\Phi$ is the non-linear function of $X_{i}$. We accounted for population-adjusted survey sampling weights and clustering at the level of primary sampling units in our analyses. We used the same set of socioeconomic factors as determinants of OPHE (2015-16 prices) using multiple linear regression. In this case, we transformed OPHE to the natural logarithm due to its positively skewed distribution. We estimated standard errors of all variables and these can be provided on request. We used STATA, version 15.1, and MS Excel, 2013, for all analyses.

\section{Results}

Across all years, OPHE at 2015-16 constant prices was

\begin{tabular}{|c|c|c|c|c|}
\hline \multirow[t]{2}{*}{ Item } & \multicolumn{4}{|c|}{ Out-of-pocket health payment: weighted mean ( $95 \%$ CI) } \\
\hline & 2001-02 & $2005-06$ & 2010-11 & $2015-16$ \\
\hline \multicolumn{5}{|l|}{ Province } \\
\hline National & $7561(7223-7899)$ & $10364(9767-10961)$ & $8660(8207-9113)$ & $11627(11055-12198)$ \\
\hline Punjab & $6714(6309-7118)$ & 10308 (9526-11090) & $8609(8022-9196)$ & $12396(11511-13280)$ \\
\hline Sindh & $9445(8587-10303)$ & $8705(8046-9363)$ & $6394(5852-6936)$ & $8235(7713-8757)$ \\
\hline KPK & $8753(7745-9762$ & $15325(13237-17413)$ & $14103(12283-15923)$ & $14810(13455-16164)$ \\
\hline Baluchistan & $5148(4412-5884)$ & $5168(3680-6657$ & $4618(4092-5144)$ & 9947 (7975-11919) \\
\hline \multicolumn{5}{|l|}{ Residence } \\
\hline Rural & $8641(7891-9391)$ & 10346 (9413-11279) & $8127(7565-8689)$ & $11671(10823-12519)$ \\
\hline Urban & $7121(6769-7472)$ & $10374(9608-11140)$ & 8933 (8314-9551) & $11545(11052-12038)$ \\
\hline \multicolumn{5}{|l|}{ Quintile $^{a}$} \\
\hline Poorest & $3566(3368-3765)$ & $4822(4609-5036$ & $5008(4746-5270)$ & $5526(5110-5942)$ \\
\hline 2nd poorest & $4846(4592-5101)$ & $7063(6682-7443)$ & $6534(6100-6968)$ & 7519 (7058-7979) \\
\hline Middle & $6269(5936-6602)$ & 8952 (8373-9532) & 7467 (7037-7897) & $10183(9580-10786)$ \\
\hline 2nd richest & $8161(7670-8652)$ & $10645(9851-11432)$ & $9325(8711-9939$ & $13523(12726-14321)$ \\
\hline Richest & $14964(13687-16240)$ & $20343(17826-22859)$ & $14972(13130-16814)$ & $21384(19271-23498)$ \\
\hline
\end{tabular}
highest in 2015-16 in KPK province, in the rural areas and

All estimates are in Pakistan rupees (PKR), 2015-16 constant prices.

$\mathrm{CI}=$ confidence interval.

KPK = Khyber Pakhtunkhwa

${ }^{a}$ Quintile of adult equivalent household total expenditure. 
Figure 2 Share of out-of-pocket health expenditure in relation to total expenditure (TE) and non-subsistence expenditure (NFE), Pakistan, 2001-02 to 2015-16

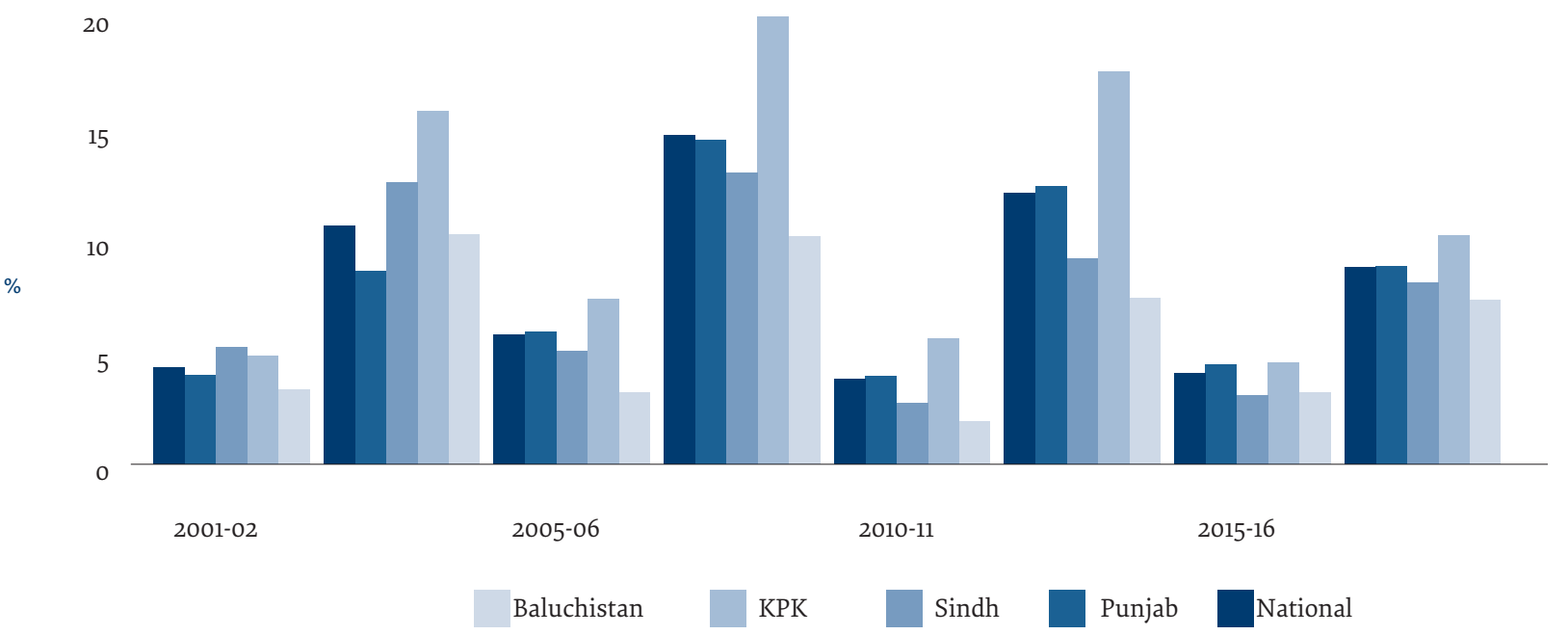

in the richest quintiles (Table 3). The disparity in OPHE among the provinces was highest in 2005-06 (KPK PKR 15325 and Baluchistan PKR 5168).

The share of OPHE in the household total and nonsubsistence expenditure slightly decreased over the period of the analysis (Figure 2).

At national level, $\mathrm{CH}_{10}$ and $\mathrm{CH}_{25}$ had generally decreased, yet this trend was inconsistent. In 2005-06, $\mathrm{CH}_{10}$ and $\mathrm{CH}_{25}$ had increased from in 2001-02, while in 2010-11 it had decreased (Table 4). Although in 2015-16 the incidence of $\mathrm{CH}$ decreased from the 2001-02 levels, in comparison with 2010-11, it had increased. Nationally, the incidence of $\mathrm{CH}$ was lowest in 2010-11 and highest in 2005-06. Among the provinces, $\mathrm{CH}_{10}$ and $\mathrm{CH}_{25}$ were highest in KPK and lowest in Baluchistan. However, in 2 provinces, Punjab and Baluchistan, $\mathrm{CH}_{10}$ had increased over the years while $\mathrm{CH}_{25}$ had increased in Baluchistan.
$\mathrm{CH}_{10}$ and $\mathrm{CH}_{25}$ had followed similar trends except that in Baluchistan $\mathrm{CH}_{10}$ had increased and $\mathrm{CH}_{25}$ had decreased between 2015-16 and 2001-02.

The incidence of financial catastrophe had generally moved away from the rich over the years towards the poor: more of the poor population were encountering $\mathrm{CH}$ than the rich population except in Baluchistan where, by 2015 , proportionately more non-poor encountered $\mathrm{CH}$ than poor. The values of $\mathrm{CI}$ were generally more inequitable (pro-poor) for $\mathrm{CH}_{25}$ then $\mathrm{CH}_{10}$. Unlike the incidence of catastrophic headcount: that was lowest, i.e. more inequitable, in 2010-11 than other years.

Impoverishment from OPHE slightly decreased in 2015-16 compared with in 2001-02 (Table 5). In Punjab and Baluchistan, $\mathrm{H}_{\mathrm{imp}}$ had increased in 2015-16 compared with in 2001-02. Comparing the years, at the national level and in Punjab, $\mathrm{H}_{\text {imp }}$ was highest in 2005-06 and

\begin{tabular}{|c|c|c|c|c|c|c|c|c|c|c|}
\hline \multirow[t]{3}{*}{ Item } & \multicolumn{4}{|c|}{ Year } & \multicolumn{6}{|c|}{ Change over time (\%) 2005-06 } \\
\hline & 2001-02 & 2005-06 & $2010-11$ & 2001-02 & & & & & & \\
\hline & $\mathbf{A}$ & B & C & D & B-A & C-B & C-A & D-C & D-B & D-A \\
\hline \multicolumn{11}{|c|}{ OOP exceeding $10 \%$ of total expenditure } \\
\hline National & $9.6(0.1)$ & $13.8(-0.1)$ & $5.9(-0.0)$ & $8.24(0.0)$ & $4.2(-0.2)$ & $-7.9(0.0)$ & $-3.7(-0.2)$ & $2.4(0.06)$ & -5.57 .1 & $-1.4(-0.1)$ \\
\hline Punjab & $9.2(0.2)$ & $15.8(-0.1)$ & $7.1(-0.0)$ & $10.8(0.0)$ & $6.6(-0.3)$ & $-8.7(0.0)$ & $-2.1(-0.2)$ & $3.7(0.0)$ & $-5.0(5.4)$ & $1.6(-0.2)$ \\
\hline Sindh & $10.9(-0.0)$ & $7.3(-0.2)$ & $1.4(-0.1)$ & $3.0(-0.1)$ & $-3.6(-0.2)$ & $-5.9(0.1)$ & $-9.5(-0.1)$ & $1.7(0.1)$ & $-4.2(18.8)$ & $-7.8(-0.0)$ \\
\hline KPK & $11.5(0.2)$ & $21.1(0.0)$ & $10.9(0.1)$ & $8.6(0.1)$ & $9.6(-0.2)$ & $-10.3(0.0)$ & $-0.7(-0.2)$ & $-2.2(-0.0)$ & $-12.5(3.6)$ & $-2.9(-0.2)$ \\
\hline Baluchistan & $3.6(-0.1)$ & $1.8(0.1)$ & $0.5(-0.1)$ & $4.5(0.3)$ & $-1.8(0.2)$ & $-1.6(-0.2)$ & $-3.5(0.0)$ & $4.3(0.3)$ & $2.7(14.7)$ & $0.9(0.3)$ \\
\hline \multicolumn{11}{|c|}{ OOP exceeding $25 \%$ of non-food expenditure } \\
\hline National & $9.5(0.0)$ & $15.5(-0.1)$ & $9.9(-0.2)$ & $6.0(-0.1)$ & $6.0(-0.2)$ & $-5.5(-0.1)$ & $0.5(-0.2)$ & $-4.0(0.1)$ & $-9.4(5.1)$ & $-3.5(-0.1)$ \\
\hline Punjab & $7.6(0.2)$ & $16.5(-0.1)$ & $11.2(-0.2)$ & $7.8(-0.1)$ & $9.0(-0.3)$ & $-5.3(-0.1)$ & $3.6(-0.4)$ & $-3.4(0.1)$ & $-8.8(4.6)$ & $0.2(-0.3)$ \\
\hline Sindh & $9.7(-0.2)$ & $9.0(-0.3)$ & $3.1(-0.4)$ & $2.9(-0.2)$ & $-0.7(-0.1)$ & $-5.9(-0.2)$ & $-6.6(-0.2)$ & $-0.2(0.2)$ & $-6.1(5.5)$ & $-6.8(-0.2)$ \\
\hline KPK & $16.8(0.1)$ & $26.9(-0.1)$ & $19.8(-0.1)$ & $5.9(-0.0)$ & $10.1(-0.1)$ & $-7.1(-0.1)$ & $3.0(-0.2)$ & $-13.9(0.1)$ & $-21.0(5.3)$ & $-10.9(-0.1)$ \\
\hline Baluchistan & $9.4(-0.2)$ & $2.4(0.0)$ & $0.7(-0.5)$ & $2.0(0.3)$ & $-7.0(0.2)$ & $-1.7(-0.5)$ & $-8.6(-0.3)$ & $1.3(0.8)$ & $-0.4(26.2)$ & $-7.3(0.5)$ \\
\hline
\end{tabular}

Table shows proportion of households (\% points) that have encountered financial catastrophe from OPHE. Concentration indices of CH are provided in parenthesis. All estimates account for sampling weights (adjusted for the respective year population estimates) and clustering at the level of primary sampling units. 


\begin{tabular}{|c|c|c|c|c|c|c|c|c|c|c|}
\hline \multirow[t]{3}{*}{ Items } & \multicolumn{4}{|c|}{ Year } & \multicolumn{6}{|c|}{ Change over time (\%) } \\
\hline & \multirow{2}{*}{$\begin{array}{c}\text { 2001-02 } \\
\text { A }\end{array}$} & \multirow{2}{*}{$\begin{array}{c}2005-06 \\
\text { B }\end{array}$} & \multirow{2}{*}{$\begin{array}{c}2010-11 \\
C\end{array}$} & \multirow{2}{*}{$\begin{array}{c}2015-16 \\
\text { D }\end{array}$} & \multirow[b]{2}{*}{$\mathbf{B}-\mathbf{A}$} & \multirow[b]{2}{*}{$\mathbf{C}-\mathbf{B}$} & \multirow[b]{2}{*}{$\mathbf{C}-\mathbf{A}$} & \multirow[b]{2}{*}{ D-C } & \multirow[b]{2}{*}{ D-B } & \multirow[b]{2}{*}{$\mathbf{D}-\mathbf{A}$} \\
\hline & & & & & & & & & & \\
\hline \multicolumn{11}{|l|}{ National } \\
\hline Pre-payment & 66.3 & 68.2 & 60.7 & 48.2 & 2.0 & -7.6 & -5.6 & -12.5 & -20.0 & -18.0 \\
\hline Post-payment & 69.4 & 71.7 & 63.4 & 51.3 & 2.2 & -8.3 & -6.0 & -12.1 & -20.4 & -18.1 \\
\hline Absolute difference & 3.2 & 3.4 & 2.7 & 3.1 & 0.3 & -0.7 & -0.4 & 0.4 & -0.4 & -0.1 \\
\hline \multicolumn{11}{|l|}{ Punjab } \\
\hline Pre-payment & 62.9 & 67.6 & 61.5 & 46.8 & 4.7 & -6.1 & -1.4 & -14.7 & -20.8 & -16.2 \\
\hline Post-payment & 66.1 & 71.3 & 64.4 & 50.3 & 5.3 & -7.0 & -1.8 & -14.0 & -21.0 & -15.8 \\
\hline Absolute difference & 3.2 & 3.8 & 2.8 & 3.6 & 0.6 & -0.9 & -0.3 & 0.7 & -0.2 & 0.4 \\
\hline \multicolumn{11}{|l|}{ Sindh } \\
\hline Pre-payment & 66.3 & 63.5 & 55.5 & $47 \cdot 3$ & -2.9 & -8.0 & -10.8 & -8.3 & -16.2 & -19.1 \\
\hline Post-payment & 69.3 & 65.83 & 57.05 & 49.34 & -3.47 & -8.8 & -12.2 & -7.7 & -16.5 & -20.0 \\
\hline Absolute difference & 2.97 & 2.35 & 1.55 & 2.10 & -0.62 & -0.80 & -1.42 & 0.55 & -0.3 & -0.9 \\
\hline \multicolumn{11}{|l|}{ KPK } \\
\hline Pre-payment & 76.62 & 72.12 & 64.28 & 48.79 & -4.50 & -7.84 & -12.34 & -15.48 & -23.32 & -27.82 \\
\hline Post-payment & 80.56 & 76.92 & 68.98 & 51.65 & -3.64 & -7.94 & -11.59 & -17.33 & -25.27 & -28.92 \\
\hline Absolute difference & 3.95 & 4.80 & 4.7 & 2.85 & 0.86 & -0.10 & 0.75 & -1.85 & -1.95 & -1.09 \\
\hline \multicolumn{11}{|l|}{ Baluchistan } \\
\hline Pre-payment & 74.52 & 85.09 & 64.57 & 63.83 & 10.56 & -20.52 & -9.95 & -0.74 & -21.26 & -10.69 \\
\hline Post-payment & 76.60 & 86.31 & 66.05 & 66.76 & 9.72 & -20.27 & -10.55 & 0.72 & -19.55 & -9.83 \\
\hline Absolute difference & 2.07 & 1.23 & 1.47 & 2.93 & -0.85 & 0.25 & -0.6 & 1.46 & 1.71 & 0.86 \\
\hline $\begin{array}{l}\text { National poverty line } \\
\text { PKR (US\$) per person/ } \\
\text { month }\end{array}$ & $\begin{array}{c}1026 \\
(16.57)\end{array}$ & $\begin{array}{c}1278 \\
(21.47)\end{array}$ & $\begin{array}{c}2333 \\
(27.38)\end{array}$ & $\begin{array}{c}3250 \\
(30.96)\end{array}$ & - & - & - & - & - & - \\
\hline
\end{tabular}

Table shows impoverishment $\left(\mathrm{H}_{\text {imp }}\right)$ as the absolute difference between post-OOP payment poverty headcount (\% points) and pre-OOP payment poverty headcount (\% points).

The official poverty line is on a per person per month basis while in the analysis a per person per year poverty line is used. Population estimates are interpolated between the 1998 census and the 2017 census. In the analyses, the monthly poverty line is converted to annual estimates.

lowest in 2010-11. For all years and across all provinces and at national level, $\mathrm{H}_{\text {imp }}$ was highest in KPK in 2005$06(4.8 \%)$ and lowest in Baluchistan in 2005-06 (1.23\%). While generally a decrease in poverty corresponded with a decrease in OPHE impoverishment, there were a few exceptions. Between 2015-16 and 2010-11, with the exception of KPK, the poverty headcount had decreased yet the OPHE impoverishment had increased. Between 2005-06 and 2001-02, Baluchistan was the only case where the poverty headcount had increased but the impoverishment of OPHE had decreased (Table 5).

Figure 3 provides the estimates of $\mathrm{CH}_{10}, \mathrm{CH}_{25}$ and $\mathrm{H}_{\text {Imp }}$ for population. Here the proportion of the population affected by financial catastrophe is generally higher than that impoverished due to OPHE. Financial catastrophe affected more people in 2005-06 and in Punjab province.

Analysis of socioeconomic and demographic factors revealed that: a household in a rural area, in KPK and in 2005-06; and a household with 1-4 members, and the head of the household is male, very young or very old, with fewer years of schooling and unmarried were more likely to encounter $\mathrm{CH}_{10}, \mathrm{CH}_{25}$ or $\mathrm{H}_{\text {imp }}$ then their respective reference groups (Table 6).

\section{Discussion}

We found a small decrease in the financial catastrophe and impoverishment of OPHE in 2001-2015. We verified that national-level estimates of these are not consistent across all provinces. Nationally, the incidence of financial catastrophe of OPHE decreased but in 2 provinces, the trends were reversed. Our findings are robust, using national survey data with a population-representative sample and common methods of tracking progress on financial risk protection (18). Our approach using basic development needs and subsistence expenditure in estimating impoverishment and catastrophe of OPHE respectively draws from consequentialist ethics that poverty is multidimensional and food is just one aspect of it $(19,20)$. We could not analyse the financial hardship of OPHE in the context of disease patterns, demographic features and use of health services because the unit of analysis for OPHE in the Household Integrated Economic Survey is the household. Comparison across years needs careful interpretation due to the difference in the number of items on OPHE in the Household Integrated Economic Surveys.

$\mathrm{Xu}$ et al. and Wagstaff et al. found a positive relationship between catastrophic incidence and Gini 


\begin{tabular}{|c|c|c|c|c|c|c|c|c|c|}
\hline \multirow{3}{*}{$\begin{array}{l}\text { Characteristic } \\
\text { Female head } \\
\text { Male head }\end{array}$} & \multirow{2}{*}{$\begin{array}{c}\text { OPHE } \\
\text { Frequency (\%) } \\
8.21\end{array}$} & \multicolumn{2}{|c|}{$\begin{array}{c}\log _{\mathrm{OPHE}} \\
\text { Coefficient }\end{array}$} & \multicolumn{2}{|c|}{$\begin{array}{c}\mathrm{CH}_{10} \\
\text { Predicted } \\
\text { probability }\end{array}$} & \multicolumn{2}{|c|}{$\begin{array}{c}\mathrm{CH}_{25} \\
\text { Predicted } \\
\text { probability }\end{array}$} & \multicolumn{2}{|c|}{$\begin{array}{c}\mathbf{H}_{\mathrm{imp}} \\
\text { Predicted } \\
\text { probability }\end{array}$} \\
\hline & & - & \multirow[b]{2}{*}{$* * *$} & 6.58 & \multirow[b]{2}{*}{$* * *$} & \multicolumn{2}{|l|}{8.40} & \multicolumn{2}{|l|}{2.59} \\
\hline & 91.79 & 0.10 & & 8.11 & & \multicolumn{2}{|l|}{8.74} & \multicolumn{2}{|l|}{2.96} \\
\hline \multicolumn{10}{|l|}{ Age of head (years) } \\
\hline$\leq 25$ & 4.82 & 0.06 & $* *$ & 9.01 & $* *$ & 10.02 & $* *$ & 3.79 & \\
\hline $26-35$ & 20.51 & -0.03 & * & 8.44 & $* * *$ & 9.46 & $* * *$ & 3.07 & ** \\
\hline $36-45$ & 28.09 & -0.11 & $* * *$ & 6.55 & $* * *$ & 7.40 & $* * *$ & 2.50 & $* * *$ \\
\hline $46-55$ & 23.20 & - & & 7.40 & $* * *$ & 7.88 & $* * *$ & 2.63 & $* * *$ \\
\hline $56-65$ & 15.44 & 0.12 & $* * *$ & 8.74 & $* * *$ & 9.09 & *** & 3.19 & * \\
\hline $65^{+}$ & 7.93 & 0.24 & $* * *$ & 10.45 & & 11.46 & & 3.76 & \\
\hline \multicolumn{10}{|l|}{ Education of head } \\
\hline No schooling & 43.41 & 0.02 & & 9.04 & $* * *$ & 9.96 & $* * *$ & 3.34 & *** \\
\hline Primary & 15.83 & 0.02 & & 8.56 & $* * *$ & 9.09 & $* * *$ & 3.34 & $* * *$ \\
\hline High school & 25.17 & -0.02 & & 7.36 & $* * *$ & 7.69 & $* * *$ & 2.63 & $* * *$ \\
\hline Intermediate/ college & 5.95 & - & & 6.45 & $* * *$ & 6.37 & $* *$ & 2.17 & * \\
\hline Graduate \& above & 9.64 & 0.06 & $* *$ & 4.59 & & 5.04 & & 1.72 & \\
\hline Head unmarried & 9.88 & & & 8.35 & & 9.14 & & 2.93 & \\
\hline Head currently married & 90.12 & 0.05 & $* * *$ & 7.90 & & 8.65 & & 2.92 & \\
\hline \multicolumn{10}{|l|}{ Household size } \\
\hline $1-4$ & 22.98 & - & & 9.44 & & 11.91 & & 3.80 & \\
\hline $5-6$ & 29.39 & 0.25 & $* * *$ & 7.56 & $* * *$ & 8.33 & $* * *$ & 2.95 & *** \\
\hline 7-9 & 31.25 & 0.47 & $* * *$ & 7.39 & $* * *$ & 7.61 & $* * *$ & 2.59 & $* * *$ \\
\hline $10+$ & 16.37 & 0.84 & $* * *$ & 7.57 & $* * *$ & 7.18 & $* * *$ & 2.28 & $* * *$ \\
\hline \multicolumn{10}{|l|}{ Residence } \\
\hline Urban & 37.45 & - & & 7.25 & & 7.77 & & 3.06 & \\
\hline Rural & 62.55 & 0.02 & $* *$ & 8.36 & $* * *$ & 9.25 & $* * *$ & 2.84 & * \\
\hline \multicolumn{10}{|l|}{ Quintile } \\
\hline 1 & 16.46 & - & & $7 \cdot 56$ & $* * *$ & 10.90 & $* * *$ & 0.18 & $* * *$ \\
\hline 2 & 18.61 & 0.28 & $* * *$ & 7.11 & $* * *$ & 9.10 & $* * *$ & 1.49 & ** \\
\hline 3 & 20.38 & 0.46 & $* * * *$ & 7.52 & $* * *$ & 8.65 & $* * *$ & 4.24 & $* * *$ \\
\hline 4 & 21.21 & 0.66 & $* * *$ & 8.33 & $* *$ & 7.96 & $* *$ & 6.41 & $* * *$ \\
\hline 5 & 23.34 & 1.05 & $* * *$ & 9.11 & & 7.15 & & 1.85 & \\
\hline \multicolumn{10}{|l|}{ Province } \\
\hline Punjab & 42.87 & -0.35 & $* * *$ & 9.43 & $* * *$ & 9.24 & $* * *$ & 3.18 & ** \\
\hline Sindh & 25.19 & -0.24 & $* * *$ & 5.28 & & 5.89 & & 2.28 & \\
\hline KPK & 19.50 & - & & 11.49 & $* * *$ & 14.63 & $* * *$ & 3.80 & $* * *$ \\
\hline Baluchistan & 12.43 & -0.58 & $* * *$ & 2.63 & $* * *$ & 3.64 & $* * *$ & 1.92 & $* * *$ \\
\hline \multicolumn{10}{|l|}{ Year } \\
\hline $2001-02$ & 20.68 & - & & 9.03 & $* * *$ & 9.73 & $* * *$ & 3.31 & \\
\hline $2005-06$ & 21.92 & 0.31 & $* * *$ & 12.25 & & 13.80 & & 3.19 & \\
\hline $2010-11$ & 23.16 & 0.31 & $* * *$ & 5.20 & $* * *$ & 8.87 & $* * *$ & 2.70 & ** \\
\hline $2015-16$ & 34.25 & 0.36 & $* * *$ & 6.38 & $* * *$ & 4.66 & $* * *$ & 2.68 & ** \\
\hline
\end{tabular}

Predicted probabilities in column 4-6 are obtained from Probit regression while coefficient (in column 3) are obtained from multiple linear regression on log of OPHE. All estimates account for population weights and survey sampling.

For Probit regression, the dependent variable is binary taking value 1 if a household had encountered a catastrophe $\mathrm{CH}_{10}, \mathrm{CH}_{25}$ or impoverished ( $\mathrm{H}_{\mathrm{imp}}$ ) due to OOP health payments. Level of significance: ${ }^{* *}=1 \%,{ }^{* *}=5 \%$, and ${ }^{*}=10 \%$.

KPK = Khyber Pakhtunkhwa.

Index of inequality (7,12). In the context of HIC, Van Ourti et al., using European Panel data (1994-2001), found that achieving income growth and social inequalities will only reconcile if income distribution remains equitable (21). Van Doorslaer et al. associated low levels of public financing of health with higher incidences of financial 


\section{Figure 3 Population in Pakistan affected by out-of-pocket health expenditure, $\mathrm{H}_{\mathrm{imp}}, \mathrm{CH}_{10}, \mathrm{CH}_{25}, 2001-02$ to 2015-16}

25

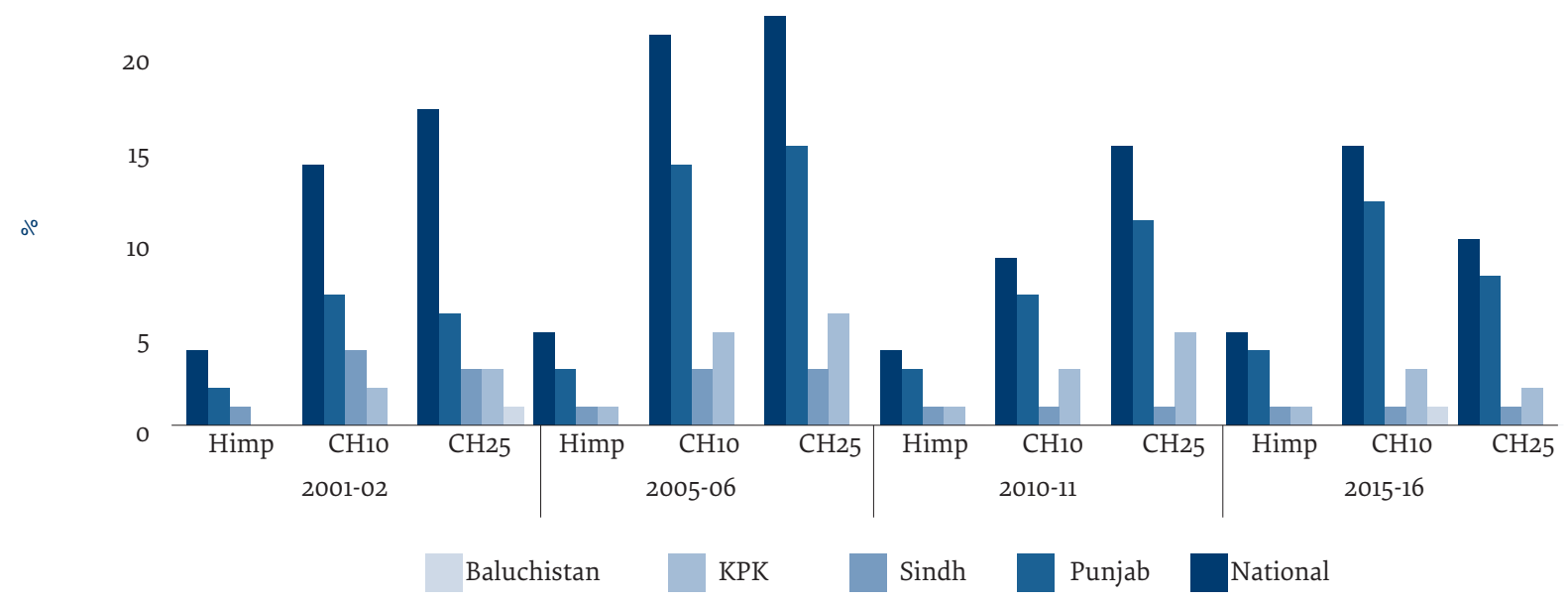

hardship from OPHE (6). Wagner et al. found that functioning a public sector contributes to better health and lower levels of financial hardships from OPHE (22). Our findings confirm both of these phenomena; for example, in 2005-06 the GDP growth rate and income-related inequalities (GINI Index) were highest (Table 2). Coupled with the lowest share of the public in total health expenditure, the incidence of financial hardship was highest in 2005-06. These trends were reversed in 2010-11: lowest GDP growth rate, lowest income-related inequalities, highest share of the public in total health care expenditure and lowest incidence of financial hardship.

The declining trend for financial catastrophe in our analysis contrasts with analyses from India (2003-2010) and the Islamic Republic of Iran (1993/94-2011/12), where the incidence of financial catastrophe had increased (24,32).

The high incidence of financial hardships from OPHE in $\mathrm{KPK}$ is similar to the findings of earlier research in 2004-05 (23). The majority of the population lives in rural and mountainous areas where access is poor and this delays care seeking, complicating the illness and escalating the costs of treatment. Another aspect to consider could be better health-seeking behaviour in KPK (23): among all the provinces, life expectancy at birth is highest in KPK and under-5 mortality is lowest (Table 1).

Our findings have particular relevance to the existing financial risk protection schemes that target families living below the poverty line although they do indicate that the non-poor are almost equally affected by the financial hardships of OPHE. To strengthen our argument in favour of the non-poor, we distributed $\mathrm{CH}_{10}$ and $\mathrm{CH}_{25}$ by adult equivalent total expenditure (AETE) quintiles (Table 7) but no clear direction emerged in the catastrophic incidence and AETE quintiles. The incidence of financial catastrophe $\left(\mathrm{CH}_{25}\right)$ in 2005-06 in households in KPK in the middle (30.99) and the poorest quintiles (31.63) are almost identical and are the highest across all years and provinces. Other examples include

a high incidence of financial catastrophe in the middle quintiles of KPK in 2001-02, Punjab in 2010-11 ( $\left.\mathrm{CH}_{10}\right)$ and Baluchistan in 2015-16 (Table 7).

Some of our findings conflict with common trends reported in previous research. For example, we found that small-sized households and households headed by a male are positive predictors of financial hardship while other studies have reported this to be true of families headed by females and large households (24-27). In the case of small-sized household, our findings are consistent with Van Minh (34); for male-headed households, we agree with the findings of Kumar et al. and Lu et al. $(28,29)$.

Methodological consideration for comparison across the literature includes: features of the data, for example recall period; number of items of OPHE and unit of data collection; and methods of estimating financial hardship, for example, threshold of financial catastrophe and poverty line in impoverishment. The literature on survey design indicates that by increasing the recall period the reported expenditure decreases consistently $(30,31)$. The recall period in the Household Integrated Economic Survey is similar to the recall period of OPHE in expenditure surveys used in analyses from the Islamic Republic of Iran, India and China $(28,32)$. Due to the difference in frequencies of need for outpatient and inpatient care, separate recall periods for outpatient (2-4 weeks) and inpatient (1 year) care are more appropriate, such as were used in studies from Rwanda, India, Bangladesh and Vietnam $(26,29,33,34)$. Lu et al. found that a lower level of disintegration of OPHE items creates negative reporting bias (29). We speculate an increase in the incidence of financial hardships from OPHE in 201516 for this factor.

Due to differences in the catastrophic thresholds, poverty lines and years of analysis, our estimates at national level need careful comparison with current research. For example, we used the national poverty line [PKR 2333 (US\$ 27.38) per capita per month] while the WHO report used the poverty line (US\$ 2 a day, i.e. PKR 5112 per capita per month) (10). In the catastrophic 


\begin{tabular}{|c|c|c|c|c|c|c|c|c|c|c|}
\hline \multirow[t]{2}{*}{ Year \& province } & \multicolumn{5}{|c|}{ CH10 (\%) } & \multicolumn{5}{|c|}{$\mathrm{CH}_{25}(\%)$} \\
\hline & Poorest & $\begin{array}{l}\text { 2nd } \\
\text { poorest }\end{array}$ & Middle & $\begin{array}{l}\text { 2nd } \\
\text { richest }\end{array}$ & Richest & Poorest & $\begin{array}{c}\text { 2nd } \\
\text { poorest }\end{array}$ & Middle & $\begin{array}{l}\text { 2nd } \\
\text { richest }\end{array}$ & Richest \\
\hline \multicolumn{11}{|l|}{ 2001-02 } \\
\hline Punjab & 5.0 & 6.5 & 8.4 & 11.1 & 14.1 & 4.9 & 5.8 & 6.6 & 9.2 & 10.8 \\
\hline Sindh & 13.3 & 9.6 & 8.9 & 10.2 & 12.2 & 16.5 & 9.5 & 7.7 & 7.6 & 7.6 \\
\hline KPK & 7.7 & 7.8 & 12.4 & 15.2 & 19.5 & 14.2 & 15.7 & 19.1 & 17.8 & 18.4 \\
\hline Baluchistan & 5.0 & 2.8 & 2.9 & 4.4 & 3.4 & 11.8 & 12.7 & 10.2 & 6.5 & 3.1 \\
\hline \multicolumn{11}{|l|}{$2005-06$} \\
\hline Punjab & 17.1 & 17.2 & 16.1 & 14.4 & 14.2 & 19.9 & 21.4 & 17.0 & 13.3 & 10.8 \\
\hline Sindh & 13.3 & 10.0 & 6.2 & 4.7 & 4.2 & 16.4 & 13.5 & 8.5 & 5.4 & 3.9 \\
\hline KPK & 18.5 & 20.2 & 22.6 & 22.9 & 21.3 & 31.6 & 26.6 & 31.0 & 24.4 & 20.6 \\
\hline Baluchistan & 1.6 & 1.0 & 2.8 & 1.3 & 3.6 & 1.5 & 3.3 & 2.7 & 1.5 & 3.6 \\
\hline \multicolumn{11}{|l|}{ 2010-11 } \\
\hline Punjab & 7.4 & 7.6 & 7.5 & 7.1 & 6.0 & 17.3 & 11.4 & 11.1 & 9.0 & 5.6 \\
\hline Sindh & 1.5 & 1.8 & 1.2 & 1.4 & 0.9 & 6.8 & 4.1 & 3.1 & 1.9 & 0.8 \\
\hline KPK & 9.9 & 9.4 & 10.6 & 10.5 & 14.4 & 27.2 & 21.2 & 19.8 & 15.8 & 15.4 \\
\hline Baluchistan & 0.0 & 0.4 & 0.1 & 0.0 & 0.4 & 1.3 & 1.5 & 0.9 & 0.0 & 0.4 \\
\hline \multicolumn{11}{|l|}{$2015-16$} \\
\hline Punjab & 10.0 & 10.6 & 11.4 & 11.9 & 10.1 & 9.8 & 7.4 & 7.6 & 7.7 & 6.1 \\
\hline Sindh & 3.8 & 2.7 & 2.4 & 4.0 & 2.3 & 4.8 & 3.4 & 2.2 & 2.7 & 1.3 \\
\hline KPK & 8.3 & 7.4 & 7.6 & 9.0 & 10.8 & 7.4 & 5.0 & 5.6 & 6.4 & 5.6 \\
\hline Baluchistan & 0.8 & 3.9 & 5.2 & 8.3 & 6.6 & 0.4 & 1.2 & 2.8 & 4.9 & 1.8 \\
\hline
\end{tabular}

KPK = Khyber Pakhtunkhwa.

analysis, we used non-subsistence expenditure whereas other research commonly used non-food expenditure $(10-12)$.

\section{Conclusion}

Our analysis provides some directions towards reviewing existing policies and practices; specifically:

- evaluate the impact of the financial risk protection scheme on financial hardship of OPHE;
- revisit the methods of data collection on the OPHE section of the Household Integrated Economic Survey, especially the recall period and number of items;

- explore factors of high incidence of financial hardship of OPHE in the province of KPK and in rural areas.

We expect that variation in financial hardship among provinces and in different years will assist the national and provincial governments in their priority-setting in the health sector in Pakistan.

\section{Acknowledgement}

Authors would like to thank Professor Eddy Van Doorslaer, Erasmus University for his comments.

Funding: None.

Competing interests: None declared.

\section{Variation spatio-temporelle et facteurs socio-économiques des difficultés financières dues aux dépenses de santé à la charge des patients au Pakistan \\ Résumé}

Contexte: Les difficultés financières liées aux dépenses de santé à la charge des patients constituent une préoccupation croissante pour les responsables de la santé publique dans de nombreux pays à revenu faible et intermédiaire. La variation spatio-temporelle entre les quatre provinces du Pakistan entre 2001 et 2015 fait l'objet d'un examen, ce qui aiderait à comparer la prestation des services de santé existants et les plans de protection contre les risques financiers. 
Objectifs: Dans le présent document, nous estimons les difficultés financières liées aux dépenses de santé à la charge des patients du Pakistan.

Méthodes: Les ensembles de données des enquêtes économiques intégrées auprès des ménages sont utilisés pour les périodes 2001-2002, 2005-2006, 2010-2011 et 2015-2016. Des estimations sont réalisées pour la part des dépenses de santé à la charge des ménages dans les dépenses totales et les dépenses hors subsistance ainsi que la proportion de ménages ayant subi une catastrophe financière à partir du seuil de dépenses de santé à la charge des patients supérieur ou égal à $10 \%$ des dépenses totales ou supérieur ou égal à $25 \%$ des dépenses hors subsistance. Lappauvrissement lié aux dépenses de santé à la charge des patients en utilisant les seuils nationaux de pauvreté fait de même l'objet d'une estimation. Enfin, les facteurs socio-économiques des difficultés financières liées aux dépenses de santé à la charge des patients sont examinés.

Résultats: Au fil des années, la proportion de ménages ayant subi une catastrophe financière et l'appauvrissement résultant des dépenses de santé à la charge des patients ont diminué au niveau national ( $-1,3$ point de pourcentage) et dans les provinces du Sindh $(-7,8$ points de pourcentage) et du Khyber Pakhtunkhwa ( $-2,8$ points de pourcentage). La province du Khyber Pakhtunkhwa et la période 2005-2006 ont connu la plus forte incidence de catastrophe financière (26,89 points de pourcentage) et d'appauvrissement (4,8 points de pourcentage) résultant des dépenses de santé à la charge des patients. Les ménages des zones rurales, les ménages des quintiles moyens et riches et les ménages dirigés par un homme étaient plus susceptibles de subir une catastrophe financière et de s'appauvrir en raison des dépenses de santé à la charge des patients.

Conclusion: Les variations interprovinciales des difficultés financières liées aux dépenses de santé à la charge des patients aident à définir les priorités au niveau provincial. L'impact élevé des dépenses de santé à la charge des patients dans les zones non pauvres, rurales et dans la province du Khyber Pakhtunkhwa appelle à un meilleur ciblage des plans de protection contre les risques financiers.

$$
\begin{aligned}
& \text { الاختلاف المكاني والزماني والعوامل الاجتحاعية والاقتصادية للمصاعب المالية الناجمة عن الإنفاق من الأموال الخاصة } \\
& \text { على الصحة في باكستان } \\
& \text { أشعر محمد مالك، إقبال أعظم، عامر خان، فيصل رفان انق، كنز اشودري }
\end{aligned}
$$

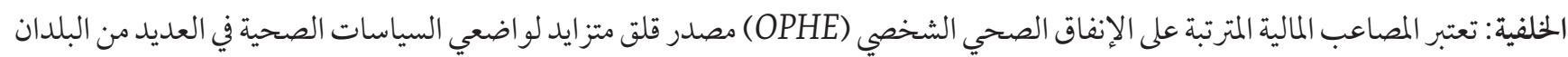

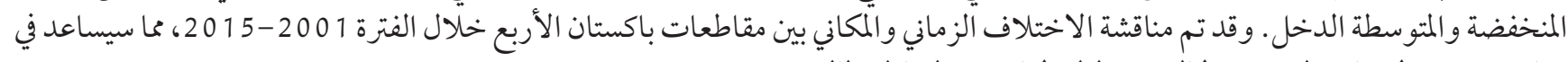
مقارنة تقديم الخدمات الصحية الحالية وخطط الحماية من الماتئة المخاطر المالية.

الأهداف: هدفت هذه الدراسة المى تقدير المصاعب المالية الناجمة عن الإنفاق من الأمو ال الخاصة على الصحة في فئ أقاليم باكستان الأربعة خلال الفترة بين عامي 2000-200 مدفت هذه 2015.

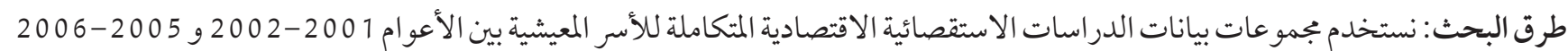

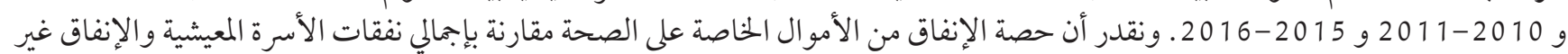

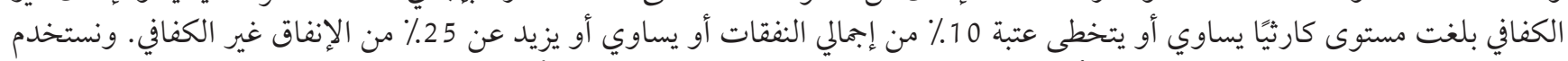

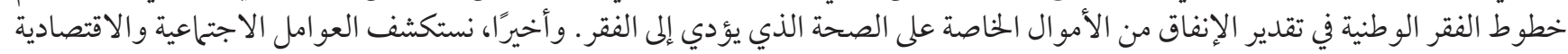

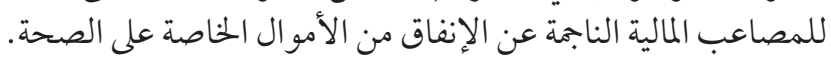

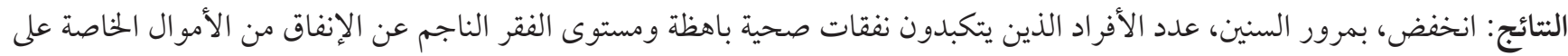

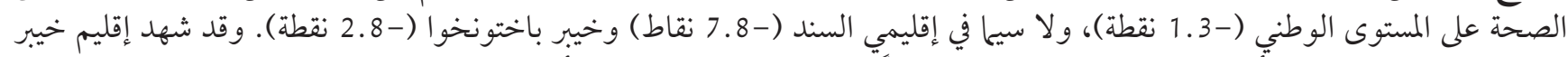

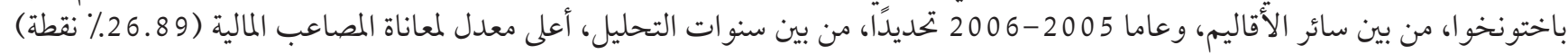

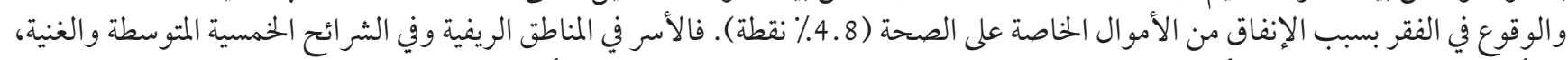

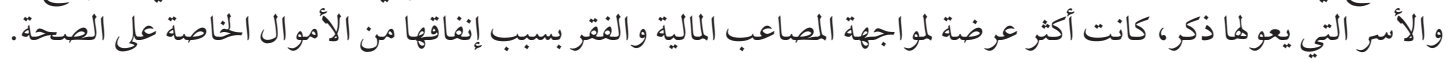

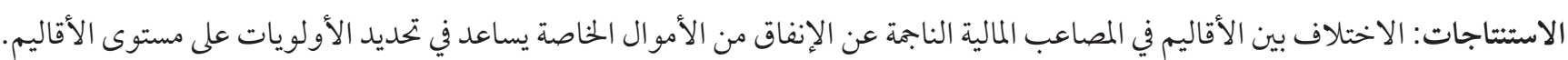

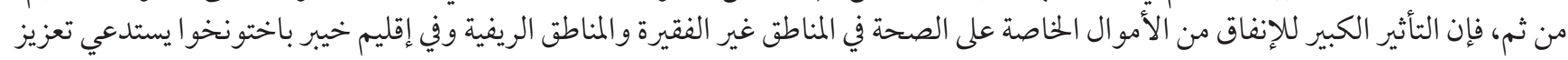
استهداف خطط الحماية من المخاطر المالية. 


\section{References}

1. Cotlear D, Nagpal S, Smith O, Tandon A, Cortez R. Going universal: how 24 developing countries are implementing universal health coverage from the bottom up. Washington, DC: World Bank; 2015. doi:10.1596/978-1-4648-0610-0

2. Pakistan Bureau of Statistics, National Health Accounts of Pakistan 2015-16. Islamabad: Pakistan Bureau of Statistics, Statistics Division; 2018.

3. Malik MA, Nahyoun AS, Rizvi A, Bhatti ZA, Bhutta ZA. Expenditure tracking and review of reproductive maternal, newborn and child health policy in Pakistan. Health Policy Plan. 2017 Jul 1;32(6):781-90. doi:10.1093/heapol/czxo21. PMID: 28334970

4. Xu K, Evans DB, Kawabata K, Zeramdini R, Klavus J, Murray CJ. Household catastrophic health expenditure: a multicountry analysis. Lancet. 2003 Jul 12;362(9378):111-7. doi:10.1016/So140-6736(03)13861-5

5. van Doorslaer E, O'Donnell O, Rannan-Eliya RP, Somanathan A, Adhikari SR, Garg CC, et al. Effect of payments for health care on poverty estimates in 11 countries in Asia: an analysis of household survey data. Lancet. 2006 Oct 14;368(9544):1357-64. doi:10.1016/S0140-6736(06)69560-3

6. van Doorslaer E, O'Donnell O, Rannan-Eliya RP, Somanathan A, Adhikari SR, Garg CC, et al. Catastrophic payments for health care in Asia. Health Econ. 2007 Nov;16(11):1159-84. doi:10.1002/hec.1209

7. Xu K, Evans DB, Carrin G, Aguilar-Rivera AM, Musgrove P, Evans T. Protecting households from catastrophic health spending. Health Aff (Millwood). 2007 Jul-Aug;26(4):972-83. doi:10.1377/hlthaff.26.4.972

8. Saksena P, Xu K, Durairaj V. The drivers of catastrophic expenditure: outpatient services, hospitalization or medicines. World health report (2010). Background paper, 21. Geneva: World health Organization; 2010.

9. PLOS Medicine Editors. The PLOS "monitoring universal health coverage" collection: managing expectations. PLoS Med. 2014 Sep 22;11(9):e1001732. doi:10.1371/journal.pmed.1001732

10. Tracking universal health coverage: first global monitoring report. Geneva: World Health Organization; 2015.

11. Tracking universal health coverage: global monitoring report. Geneva: World Health Organization; 2017.

12. Wagstaff A, Flores G, Hsu J, Smitz MF, Chepynoga K, Buisman LR, et al. Progress on catastrophic health spending in 133 countries: a retrospective observational study. Lancet Glob Health. 2018 Feb;6(2):e169-e179. doi:10.1016/S2214-109X(17)30429-1

13. Wagstaff A, Flores G, Smitz MF, Hsu J, Chepynoga K, Eozenou P. Progress on impoverishing health spending in 122 countries: a retrospective observational study. Lancet Glob Health. 2018 Feb;6(2):e180-92. doi:10.1016/S2214-109X(17)30486-2

14. Morgan, L., Actuarial Analysis of the Federal Sehat Sahulat Program. 2019, International Labour Office: Geneva. p. 50.

15. Ayub A, Khan RS, Khan SA, Hussain H, Tabassum A, Shehzad JA, Shah SS. Progress of Khyber Pakhtunkhwa (Pakistan) towards universal health coverage. J Ayub Med Coll Abbottabad. 2018 Jul-Sep;30(3):482-5. PMID:30465392

16. Health equity and financial protection report Pakistan. Washington DC: World Bank; 2012.

17. Malik MA. Universal health coverage assessment Pakistan. Karachi: Aga Khan University; 2015 (https://ecommons.aku.edu/pakistan_fhs_mc_chs_chs/203/, accessed 19 April 2021).

18. O’Donnell O, van Doorslaer E, Wagstaff A, Lindelow M.. Analyzing health equity using household survey data : a guide to techniques and their implementation. Washington DC: World Bank; 2008 (https://openknowledge.worldbank.org/handle/10986/6896 License: CC BY 3.0 IGO, accessed 19 April 2021).

19. National poverty report 2015-16. Islamabad. Ministry of Planning Development and Reforms; 2018.

20. Wing EA, ed. Pakistan economic survey 2015-2016. Islamabad: Finance Division; 2016.

21. Van Ourti T, van Doorslaer E, Koolman X. The effect of income growth and inequality on health inequality: theory and empirical evidence from the European Panel. J Health Econ. 2009 May;28(3):525-39. doi:10.1016/j.jhealeco.2008.12.005

22. Wagner AK, Graves AJ, Reiss SK, Lecates R, Zhang F, Ross-Degnan D. Access to care and medicines, burden of health care expenditures, and risk protection: results from the World Health Survey. Health Policy. 2011 May;100(2-3):151-8. doi:10.1016/j. healthpol.2010.08.004

23. Muhammad Malik A, Azam Syed SI. Socio-economic determinants of household out-of-pocket payments on healthcare in Pakistan. Int J Equity Health. 2012 Sep 4;11:51. doi:10.1186/1475-9276-11-51

24. Pandey A, Ploubidis GB, Clarke L, Dandona L. Trends in catastrophic health expenditure in India: 1993 to 2014. Bull World Health Organ. 2018 Jan 1;96(1):18-28. doi:10.2471/BLT.17.191759

25. Asare-Kumi A, Mettle F, Baidoo I, Nortey E. Catalogistico discriminant analysis: a methodology for analyzing catastrophic spending on health in statistically under-developed countries. J Mathematics Statistics. 2014;6(2):16-22. doi:10.19026/rjms.6.5808

26. Mohanty SK, Kim R, Khan PK, Subramanian SV. Geographic variation in household and catastrophic health spending in india: assessing the relative importance of villages, districts, and states, 2011-2012. Milbank Q. 2018 Mar;96(1):167-206. doi:10.1111/1468-0009.12315

27. Somkotra T, Lagrada LP. Which households are at risk of catastrophic health spending: experience in Thailand after universal coverage. Health Aff (Millwood). 2009 May-Jun;28(3):w467-78. doi:10.1377/hlthaff.28.3.w467 
28. Kumar K, Singh A, Kumar S, Ram F, Singh A, Ram U, et al. Socio-economic differentials in impoverishment effects of out-ofpocket health expenditure in China and India: evidence from WHO SAGE. PLoS One. 2015 Aug 13;10(8):e0135051. doi:10.1371/ journal.pone.0135051

29. Lu C, Liu K, Li L, Yang Y. Sensitivity of measuring the progress in financial risk protection to survey design and its socioeconomic and demographic determinants: a case study in Rwanda. Soc Sci Med. 2017 Apr;178:11-8. doi:10.1016/j.socscimed.2017.02.001

30. Deaton A. The analysis of household surveys: a microeconometric approach to development policy. Ch 1: The design and content of household surveys.Washington DC: World Bank; 2019. doi:10.1596/ 978-1-4648-1331-3.

31. Scott C, Amenuvegbe B. Effect of recall duration on reporting of household expenditures. Washington DC: World Bank; 1990.

32. Fazaeli AA, Seyedin H, Vosoogh Moghaddam A, Delavari A, Salimzadeh H, Varmazyar H, et al. Fairness of financial contribution in iranian health system: trend analysis of national household income and expenditure, 2003-2010. Glob J Health Sci. 2015 Mar 18;7(5):260-5. doi:10.5539/gjhs.v7n5p260

33. Han SM, Rahman MM, Rahman MS, Swe KT, Palmer M, Sakamoto H, et al. Progress towards universal health coverage in Myanmar: a national and subnational assessment. Lancet Glob Health. 2018 Sep;6(9):e989-97. doi:10.1016/S2214-109X(18)30318-8

34. Van Minh H, Kim Phuong NT, Saksena P, James CD, Xu K. Financial burden of household out-of pocket health expenditure in Viet Nam: findings from the National Living Standard Survey 2002-2010. Soc Sci Med. 2013 Nov;96:258-63. doi:10.1016/j. socscimed.2012.11.028

35. Lu C, Chin B, Li G, Murray CJ. Limitations of methods for measuring out-of-pocket and catastrophic private health expenditures. Bull World Health Organ. 2009 Mar;87(3):238-44, 244A-244D. doi: 10.2471/blt.08.054379 